\title{
Selected conditions of the senior tourism functioning on the example of Lower Silesia
}

\section{Vybrané podmínky fungování seniorské turistiky na príkladu Dolního Slezska}

\author{
Julita Markiewicz-Patkowska' ${ }^{1}$ Krzysztof Widawski², Piotr Oleśniewicz ${ }^{3}$ \\ ${ }^{1}$ WSB University in Wrocław, Poland \\ ${ }^{2}$ University of Wrocław, Poland \\ ${ }^{3}$ University School of Physical Education in Wrocław, Poland
}

\begin{abstract}
The article presents selected conditions of the senior tourism on the basis of a study carried out among a group of Wroclaw seniors. The theoretical introduction defines key tourism functions, with particular emphasis on the educational, cognitive, and social ones. Both the senior group and senior tourism were defined in the context of their participants, motivations, needs, season, etc. The empirical part presents the group of seniors who underwent the tests. The majority of participants were aged $60-79$ years. The authors indicated the preferred forms of tourist recreation, and characterized the main motivations, stressing the influence of the professional suggestion of the doctors, ways of traveling, length of the journey itself, and major goals. Attention was drawn to the economic situation of seniors and their personal judgment about the influence of the recreational activity on their health conditions.
\end{abstract}

\begin{abstract}
Abstrakt
Článek představuje vybrané podmínky seniorského cestovního ruchu na základě studie provedené mezi skupinou seniorů ve Wroclawi. Teoretický úvod definuje klíčové funkce cestovního ruchu, se zvláštním dưrazem na fukce vzdèlávací, kognitivní a sociální. Jak skupina seniorů tak seniorský cestovní ruch byli definováni v kontextu svých účastníků, motivací, potřeb, období atd. Vempirické ćásti je prezentována skupina seniorů, kteři podstoupili testy. Většina účastníků byla ve věku 60-79 let. Autoři uvedli preferované formy turistické rekreace, charakterizovali hlavní motivace, zdůraznili vliv odborného názoru lékařů, způsoby cestování, délku samotné cesty a hlavní cíle. Pozornost byla věnována ekonomické situaci seniorů a jejich osobnímu úsudku o vlivu rekreační aktivity na jejich zdravotní stav.
\end{abstract}

Keywords: senior tourism, tourist functions, travel, tourist motivations, health conditions

Klíčová slova: turistika seniorů, funkce turistiky, cestování, motivace turistů, zdravotní stav

\section{INTRODUCTION}

Tourism is a complex social, cultural, and economic phenomenon, fulfilling many functions (Kowalczyk, 2001; Kurek, 2007; Oleśniewicz \& Widawski, 2013). Among the most important ones is the leisure function. The regeneration of physical and mental strength is relatively very important for the senior group. In the context of this article, the socializing function of tourism is quite significant. The main element of the socializing function is forming the desired attitudes. Learning about the region qualities may be an important part of patriotic education. Getting to know other cultures teaches openness and tolerance towards other ways of organizing the world. Many tourism forms help acquire such skills as teamwork, dealing with unusual situations, etc. 
Finally, interacting with nature supports shaping ecological awareness, including the understanding of the need to take care of the natural environment (Czerwiński, 2015; Gaworecki, 2000; Gołembski, 2002; Łobożewicz \& Bieńczyk, 2001).

Aging of societies is particularly apparent in the developed countries. At the beginning of the $21^{\text {st }}$ century, slightly over $15 \%$ of the European inhabitants were above 65 years of age (Alén et al., 2012), and this situation has been changing dynamically. A senior is defined in many ways. Hossain et al. (2003) use the term senior with reference to the 55+ age group. Lee and Tideswell (2005) or Dąbrowski (2006) indicate the age of 60 years as the threshold. Generally, the senior definition criterion relates to the socioeconomic factor of retirement.

In the recent decades, senior tourism has undergone a dynamic growth. It attracts the interest of many researchers. Górska (2010) places it in the context of social tourism, emphasizing the special situation of the elderly. As shown by Darcy and Dickson (2009) or Widawski (2010, 2011), senior tourism goes hand in hand with disabilities because of the age of the participants.

Many features are assigned to senior tourism. These include the specific seasonality, which in fact is characteristic of any type of tourism. Senior tourists constitute a group taking advantage of the regional tourist offer outside the high season, as emphasized by Śniadek (2006), who at the same time points at other specific needs of the group, such as an appropriate means of transport - comfortable, fast, and cheap - or increased safety requirements. Acevedo (2003) or Huang and Tsai (2003) raise the issue of seniors' needs, especially the need for contacting other people.

There are many conditions of senior tourism development. It would be impossible to name them all, but it is worth to focus on the most important ones, indicated by tourists themselves.

\section{SELECTED CONDITIONS OF THE SENIOR TOURISM FUNCTIONING}

To examine the conditions of the senior tourism development, the authors applied the polling survey method. The studied group included 120 residents of Lower Silesia, members of the Wroclaw Senior Centre. Active persons from the senior group were tested in November 2016.

The researched group reflects the level of activity among seniors: only $17 \%$ of the responders were male. Taking into account age subgroups (Fig. 1), the largest group of seniors were those aged 60-69 years, i.e. people approaching retirement or who had just retired. They constituted half of the studied group.

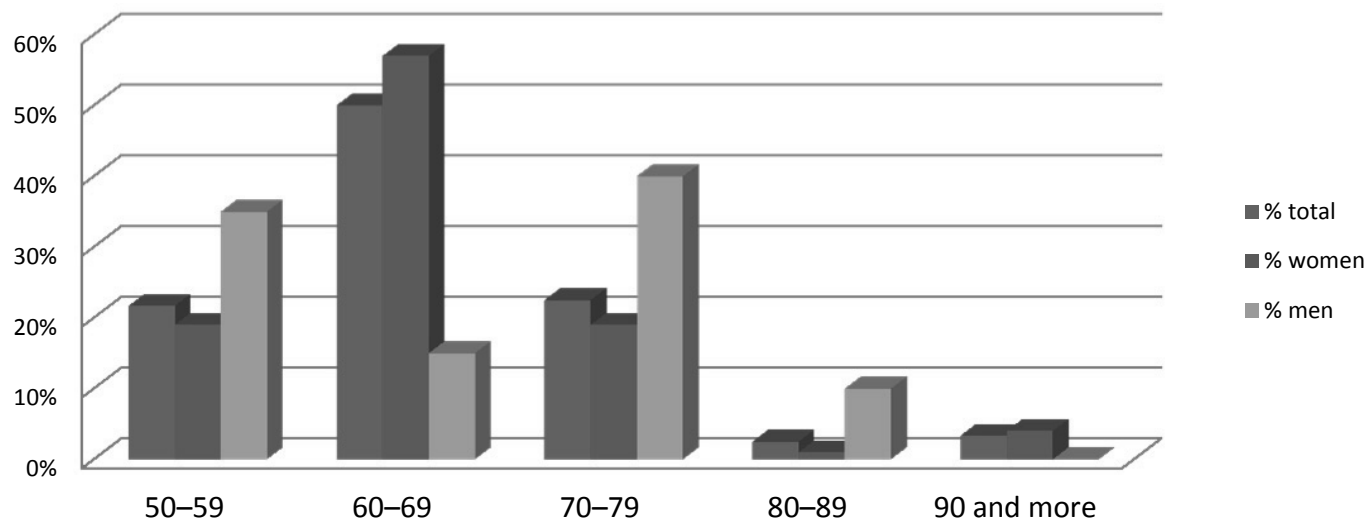

Fig. 1: Age of responders

Source: own elaboration based on research results 
Almost equally numerous age groups were the one preceding and the one following the largest one. The age range of 70-79 represented $23 \%$ of all the test participants, and the age range of $50-59$ stood for $22 \%$. The remaining age groups, $80-89$ and over 90 years, were definitely less active, which can be justified by the problems in the body functioning, attributed to this age. In both cases, these were only $3 \%$ of all responders. Most females belonged to the largest group. In the case of males, the seniors were best represented by 70 -year-olds and the oldest age group included no males.

For people undertaking tourist activities, not only for seniors - although it is the most apparent in them - one of the most important features is the availability of information, proximity to associations and clubs gathering people with similar needs. This facilitates many activities, including those in the field of tourism. As rightly noted by Kocowski (1982), in larger cities, which offer a wider access to travel agencies, sports clubs, and senior clubs, the chance for seniors to undertake tourist activity is much greater.

Among the responders, residents of cities over 500,000 people (59\% of all studied seniors) constituted the largest group. The next place of residence of the Senior Centre members was the country, although in absolute values this referred only to 18 people. Looking through the prism of gender, two out of three women lived in a large city (66\%), compared with one out of four men. Among men, the most popular place of residence (30\%) was a small town of less than 20,000 inhabitants.

It is worth to analyse the education of the study participants, which usually goes hand in hand with the awareness of the need for active lifestyle. Intellectual activity typically influences the awareness increase. Secondary education turned out the most popular in the tested group - it was declared by $42 \%$ responders. Almost every fourth person (24\%) pointed at higher vocational education, and almost every fifth (18\%) - a master's degree. The remaining $16 \%$ represented basic vocational or elementary education.

Taking the labour market situation into account, the vast majority of responders (as much as $77 \%$ ), which is not surprising, were retired people or pensioners. Ranked right after them, although with considerably lower share, were the self-employed and employed in the private sector ( $8 \%$ each). This applies mainly to the responders from the youngest age group defined in the study. The group of retired people or pensioners included $80 \%$ of the studied women, but only $60 \%$ of the studied men. Men turned out the more active group; $15 \%$ of them were still self-employed, and $10 \%$ worked in the private sector.

Marital status can and usually does translate to tourist activity. Older people, usually subjected to some form of disability or age limitations, prefer to travel accompanied. This is, among others, the group that the phenomenon of multi-customer in tourism refers to (Widawski, 2011). Nearly half of the study participants $(48 \%)$ were married. Much more often, which is worth mentioning, the married one was male (70\%) than female (43\%). Considering the fact that $1 \%$ of the study participants remained in informal partnerships, still more than a half of the studied group declared to be single. Every fourth responder was a widow/widower, almost every fifth declared to be single, and $7 \%$ had never been married. Taking into account the responders' age, one can assume that half of them encounter some barriers to tourist traveling resulting from the lack of company. This makes the membership of an association, such as the mentioned Senior Centre, even more important.

It would be quite interesting to analyse the way a tourist trip is arranged in the tested group on the basis of the declaration concerning the travel company. Traveling with friends is the most common option, referring to nearly half of the responders (46\%). Women travel with friends definitely more often (49\%) than men (only 30\%). Ranked next, the travelling company was the spouse. This preference was chosen by $27 \%$ of the responders, although it is much more common 
for married men (40\%) than married women (only 24\%). Lone trips turned out much less popular. Only $8 \%$ of responders decided to choose this type of traveling, and these were more often men ( $15 \%$ of all the studied men).

Tourist activity is greatly dependent on many factors, including the economic status. The level of salaries is important, but the way one perceives their income is equally significant for the person to undertake tourist activity. Without appropriate (positive) assessment of their financial standing, one cannot think of tourist expenses - usually not treated as indispensable. Definitely, the largest group of responders evaluated their financial situation neutrally, i.e. as being average. This applies to $65 \%$ of responders and was more often observed in women $(66 \%$ of the studied females) than men (60\%). Every fourth responder (24\%) claimed that their situation was good, and another $5 \%$ perceived it as very good. What is worth stressing is that optimism prevailed in this group. If individuals perceiving their situation as bad or very bad are taken into account, as many as $94 \%$ of the responders were mentally prepared for grater or smaller expenses not bound with essential commodities or services, i.e. tourist goods. Therefore, potentially, the economic factor was not among tourist activity inhibitors in almost any of the responders.

\section{THE PREFERRED FORMS AND THE CHARACTERISTICS OF THE SENIORS' LEISURE}

The form of physical activity, which is understandable, is greatly dependent on age. The most common form of activity among the elderly is physical activity which positively affects body and mind. There are many different forms of it. Those which were characteristic of the tested group are presented below (Fig. 2).

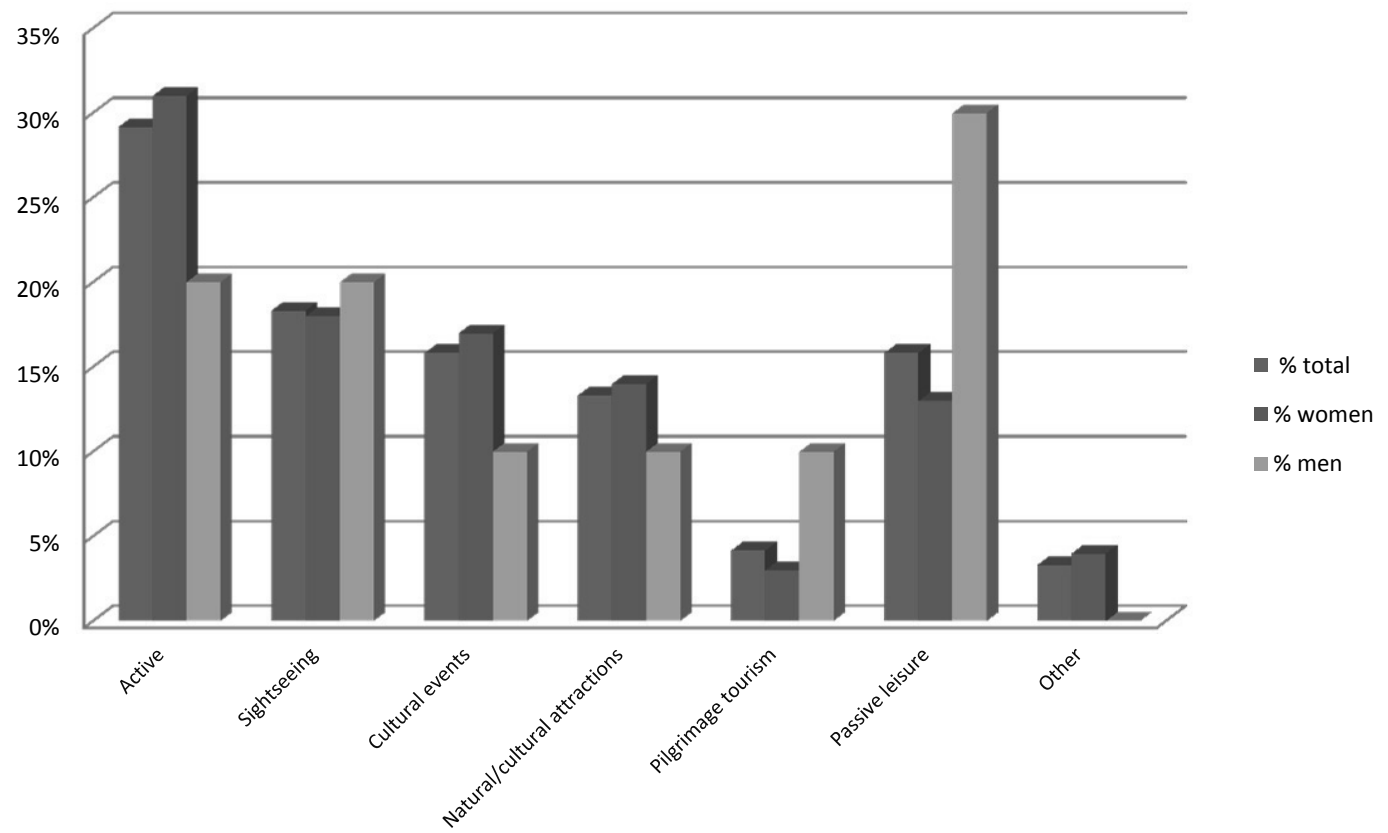

Fig. 2: The preferred forms of physical activity Source: own elaboration based on research results 
Among the seven forms of activity indicated by the responders, the most popular was active recreation, most often represented by walking, Nordic walking, and cycling. These types of activities were indicated by $29 \%$ responders. This form of activity was also the most common among the surveyed women (chosen by nearly one third of them, 31\%). Less popular, but still important for every fifth tested individual was monument sightseeing (18\%), slightly more important for men ( $20 \%$ of them) than for women $(18 \%)$. The third place was taken by two items: cultural events and passive leisure ( $16 \%$ of indications each). The passive leisure is worth noting, especially in the context of gender. This form of activity was preferred especially by men and, indicated by $30 \%$ of them, turned out the most popular among them. One fact deserves attention. If we add up the shares of such declared activities as monument sightseeing, cultural events, natural and cultural attraction sightseeing, and pilgrimage tourism, we would end up with $51 \%$ of indications of these forms of activities fulfilling the educational function of tourism, also in the group of seniors. Participation in cultural events, learning cultural or natural values, and even pilgrimage include an educational context, because, irrespective of age, each tourist trip is an open-air school.

An important question is if the physical activity improved the health conditions of the interviewees in their opinion.

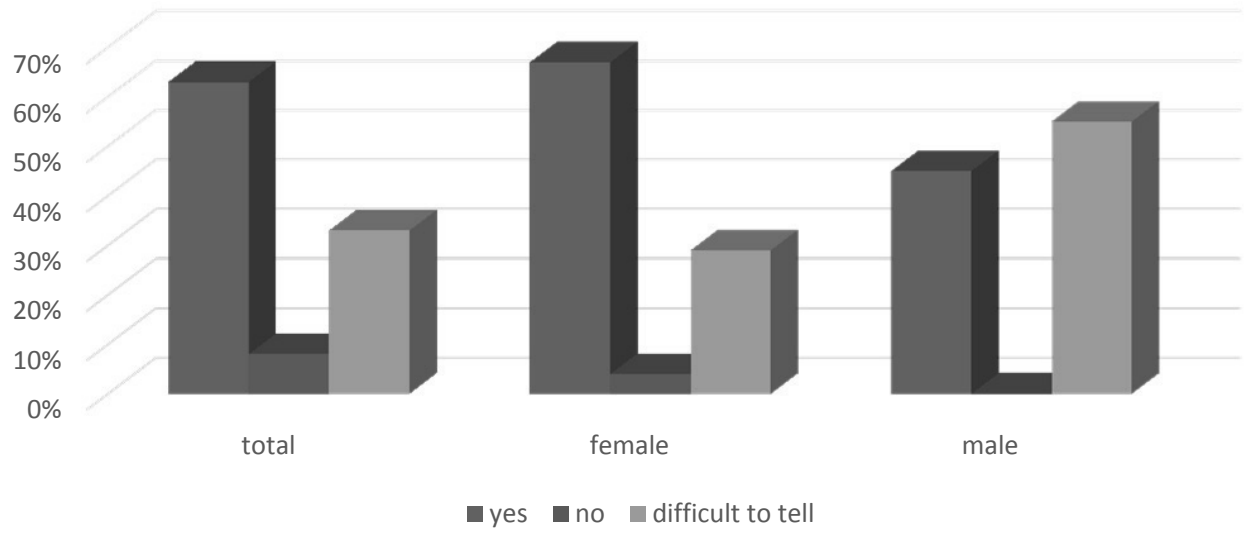

Fig. 3: The influence of physical activity on health conditions

Source: own elaboration based on research results

The positive answer usually accompanied such activity (Fig. 3). More than half of the group had no problem with an answer. In the case of $63 \%$ of the respondents, definitely the recreational activity influences positively their health. Each third person had difficulties answering the question. In their opinion both answers: positive or negative possibly did not reflect the reality. Just $8 \%$ of the respondents were quite convinced that the physical activity had not improved their health conditions. More often the female respondents tended to claim the positive influence. Two out of three ladies (67\%) pointed this answer while less than of half male population (45\%) declared the same. Just $29 \%$ of female didn't believe in such influence but in case of other sex $55 \%$ did not consider the physical activity indispensable for improving the health conditions.

Travel goals in seniors (Fig. 4) were similar as in the case of other groups of adult tourism participants, although the share of each goal possibly varied. 


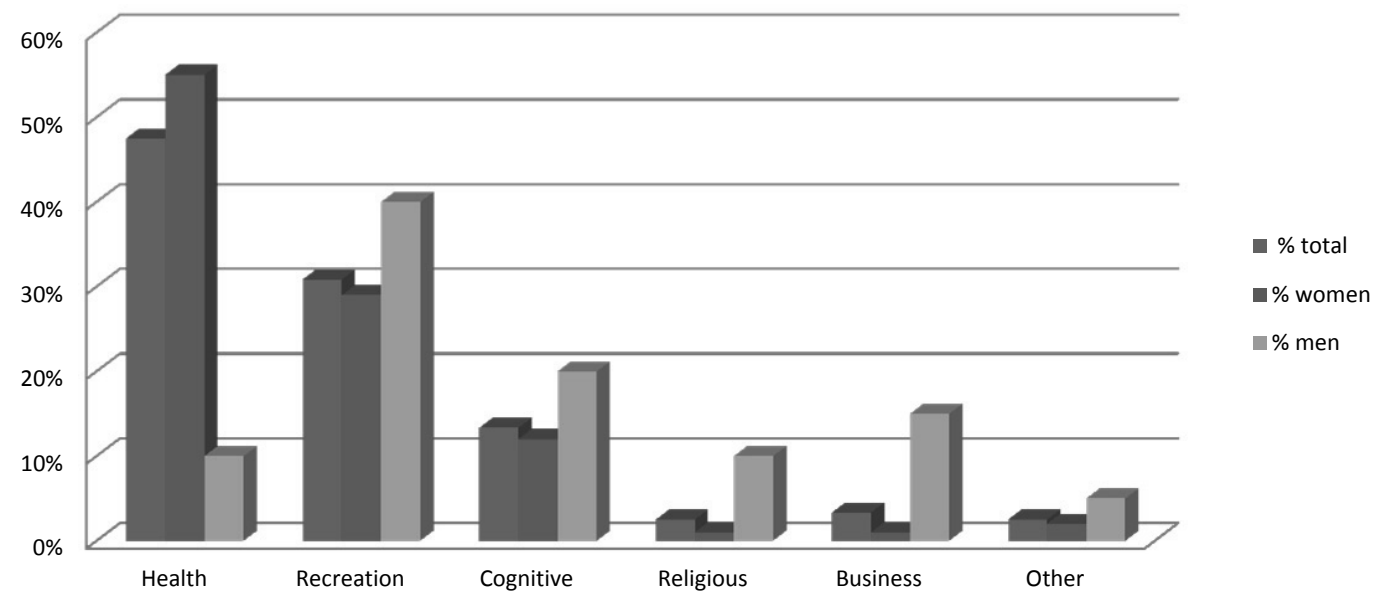

Fig. 4: Travel goals

Source: own elaboration based on research results

The most common goal was, as expected, the health-related one. The awareness of the need to take care of one's health was high in the described social group, and many activities, including those in the tourist field, were aimed at looking after the condition of one's organism, which is often deficient at this age. This applied to $48 \%$ of responders. The distribution of this awareness according to gender can be surprising. More than half of women (55\%) treated travels as a means of prolonging or diversifying therapy, while in the case of men, this tourist migration goal was the most important only for $10 \%$. The second most important objective was recreation - the most popular objective among tourists, as reported by United Nations World Tourism Organization (UNWTO, 2016). This goal was indicated by every third person, and it was the most popular traveling reason for men (40\%). The third rank belonged to the cognitive goal, which is the most important one in the context of the educational function. Every seventh individual declared that goal as their major one, and it turned out twice as much significant for males $(20 \%)$ as for females $(12 \%)$.

The factor that strengthens the travel decision is the medical advice. No matter the travel goals declared by participants in $63 \%$ of cases it is the advice of the doctor that influenced the tourist activity of the respondents. It was even a bit more in the case of the female part of the group that declared in $66 \%$ the importance of the recreational activity for the health conditions improvement suggested by the doctor. Half of the male group pointed the doctor's suggestion as the decisive factor to undertake the tourist trip.

It is worth considering what type of natural or cultural landscape is preferred by senior tourists. 


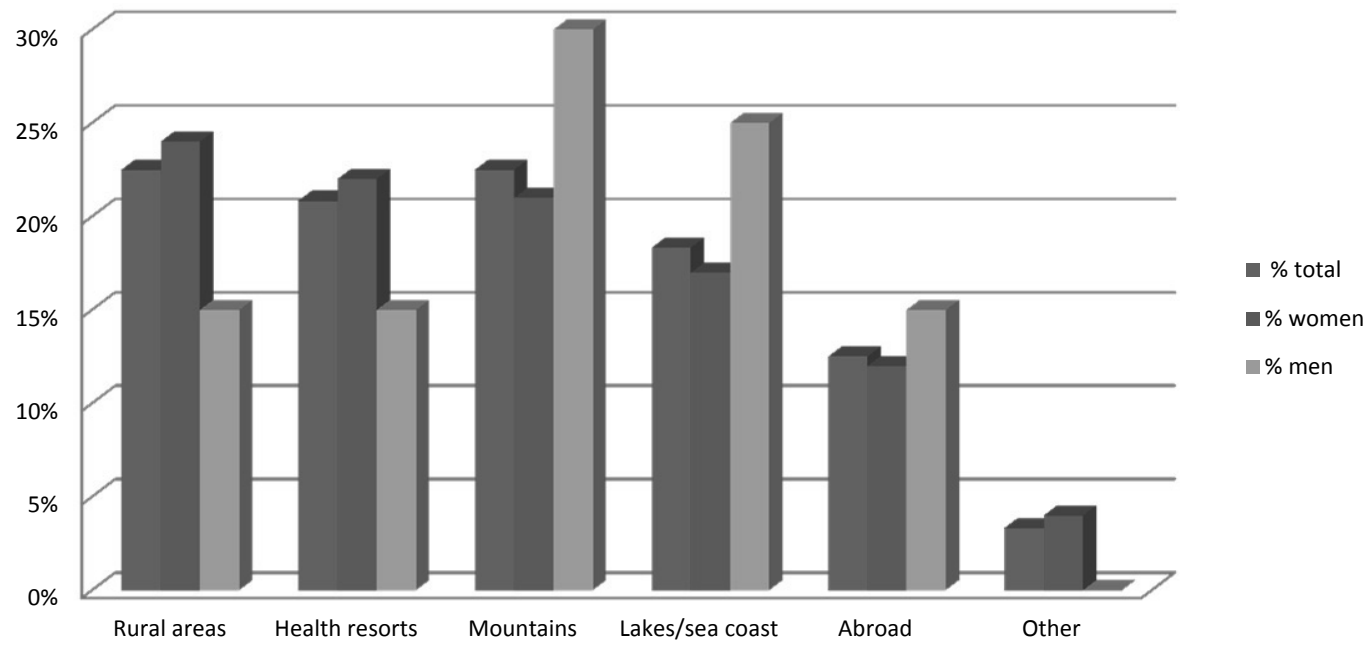

Fig. 5: Holiday destinations

Source: own elaboration based on research results

The two most popular holiday destinations (Fig. 5) were mountain areas and the countryside. Both turned out attractive for $23 \%$ of responders. Mountain landscape - treated as one of the most attractive in terms of views - was preferred especially by men: every third man chose mountains as their holiday destination. The countryside was the most popular among women - every fourth woman spent holidays in the countryside. The second rank was taken by health resorts. In the case of Lower Silesia these were scenically similar to the first two options, but they were distinguished because of their unique resort resources. The next positions were occupied by stays by the water, such as lakes or sea coasts, popular among $18 \%$ of responders. It is important to mention that regardless of the landscape type, seniors from Lower Silesia preferred domestic travels. As many as $87 \%$ of them stayed in Poland, and only every eighth left abroad.

Another issue to consider is the length of the tourist activity (Fig. 6). The travel length usually depends on many factors, such as travel costs, free time limitations or, which remains significant in the case of the tested group, health status. The responders' age can influence the preferences related to travel duration.

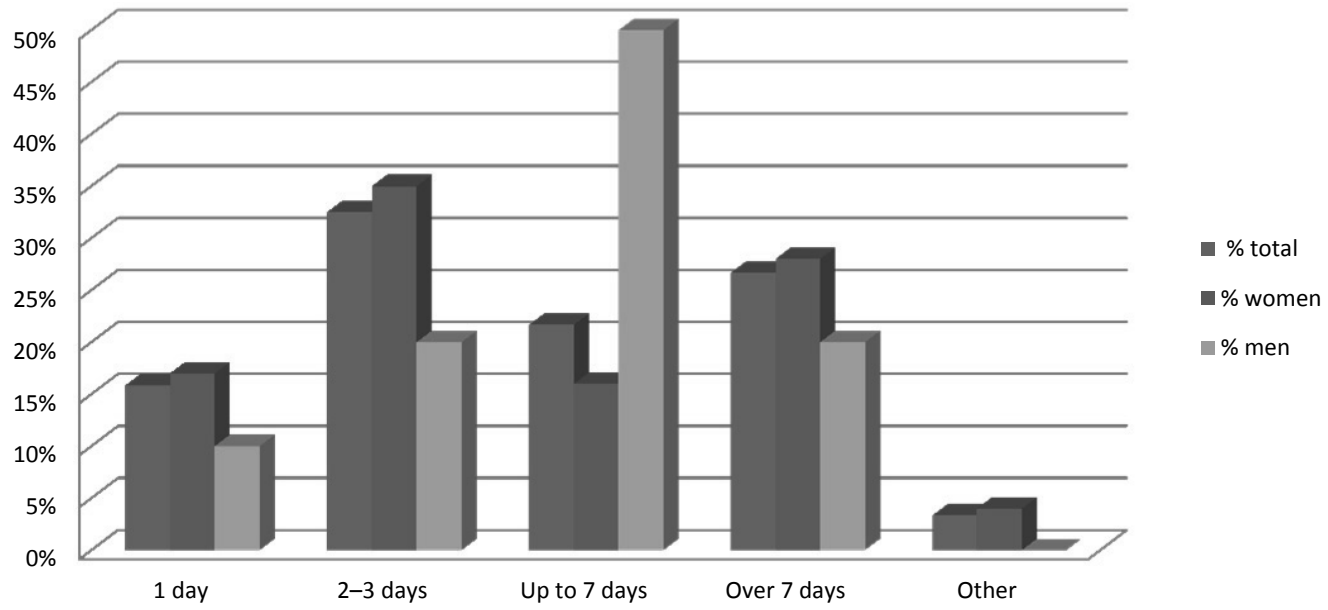

Fig. 6: Travel duration

Source: own elaboration based on research results 
Short trips were most popular among seniors in the tested group. These are called weekend trips in the literature and last up to 4 days. Every third person (33\%) preferred such travel duration. This was, at the same time, the period mostly preferred by women (35\%). Ranked second are longer trips, referred to as holiday stays, lasting over seven days. Every fourth person (27\%) chose longer trips, which usually went hand in hand with complementary cultural events. The third position was occupied by travels lasting up to one week. Every fifth person (22\%) stayed outside the place of residence for up to 7 days. This type of travel turned out popular especially among men. Half of them indicated such stay duration as preferred. Every seventh responder declared to be a oneday visitor. This option was usually dictated by economic or health-related restrictions, and had its spatial specificities. It was most often related to the immediate surroundings, and the activity was of rather recreational character.

Finally, one should ask the seniors about the tourist offer prepared for them. Without going into details concerning the offer features, most assessments were positive: the offer turned out attractive for $69 \%$ of the responders. Women were much more satisfied ( $73 \%$ of them) than men, who were equally pleased and dissatisfied with the offer.

\section{SUMMARY AND CONCLUSIONS}

Today, a growing proportion of the society are the elderly - mainly the retired and pensioners; the Polish society perceives this life season as a negative one. It is therefore important for seniors who have retired not to withdraw from active life, but to develop new forms of activity.

Senior tourism is the form of activity for people of a certain age, who bear age-related consequences. This group features not only health-related, but also financial limitations. Most of the elderly are no longer professionally active, taking advantage of their retirement benefits only. Therefore, this is their free time that could and should be used to achieve hobby-related goals. To make seniors able to pursue their cognitive passions, certain conditions must be met. Only then, education through tourism could take place. The presented study did not refer to all variables; however, certain trends can be pointed out which are characteristic of the group of seniors at least from Wroclaw, who, with some caution, can be treated as representatives of the senior group of Lower Silesia.

It is worth to emphasize the awareness of the need to take care of one's health. This is the main reason for travelling in the senior tourists group. An appropriate level of knowledge in this field affects the understanding of the need for traveling. Tourism supports human development and education in many areas - from an increased awareness of the need to take care of one's own wellbeing, through the need of recreation, to the classic form of the educational function, as in the case of implementing the cognitive goal while sightseeing, learning cultural and natural values, and participating in travels of religious character. In conclusion, the success of the educational function of senior tourism depends on many factors, ranging from motivation, through economic conditions, to social issues. Only a comprehensive approach ensures the ultimate success - enriching the tourist with knowledge and experience during the journey.

\section{References}

Acevedo, C. R. (2003). Motivos para viajar: um estudio com turistas maduros no contexto brasileiro. FACEP Pesquisa, 6(3), 78-87.

Alén, E., Domínguez, T., \& Losada, N. (2012). New opportunities for the tourism market: senior tourism and accessible tourism. In: Kasimoglu, M. (ed.). Visions for global tourism industry. Creating and sustaining competitive strategies. Rijeka, InTech, pp. 139-166. 
Czerwiński, J. (2015). Podstawy turystyki. Warszawa, CeDeWu.

Darcy, S. \& Dickson, T. (2009). A whole of life approach to tourism: the case for accessible tourism experiences. Journal of Hospitality and Tourism Management, 16(1), 32-43.

Dąbrowski, A. (ed.) (2006). Zarys teorii rekreacji ruchowej. Warszawa, ALMAMER Wyższa Szkoła Ekonomiczna, Akademia Wychowania Fizycznego.

Gaworecki, W. (2000). Turystyka. Warszawa, Polskie Wydawnictwo Ekonomiczne.

Gołembski, G. (2002). Kompendium wiedzy o turystyce. Poznań, Wydawnictwo Naukowe PWN.

Górska, E. (2010). Turystyka społeczna jako forma aktywizacji rynków turystycznych na przykładzie programów turystyki społecznej w Hiszpanii. Acta Scientiarum Polonorum, Oeconomia, 9(4), 133-142.

Hossain, A., Bailey, G., \& Lubulwa, M. (2003). Characteristics and travel patterns of older Australians: impact of population ageing on tourism. International Conference on Population Ageing and Health Modelling our Future, Canberra, 8-12 December.

Huang, L. \& Tsai, H.T. (2003). The study of senior traveler behavior in Taiwan. Tourism Management, 24(5), 561-574.

Kocowski, T. (1982). Potrzeby człowieka: koncepcja systemowa. Wrocław, Zakład Narodowy im. Ossolińskich.

Kowalczyk, A. (2001). Geografia turyzmu. Warszawa, Wydawnictwo Naukowe PWN.

Kurek, W. (2007). Turystyka. Warszawa, Wydawnictwo Naukowe PWN.

Lee, S.H. \& Tideswell, C. (2005). Understanding attitudes towards leisure travel and the constraints faced by senior Koreans. Journal of Vacation Marketing, 11(3), 249-263.

Łobożewicz, T. \& Bieńczyk, G. (2001). Podstawy turystyki. Warszawa, Wyższa Szkoła Ekonomiczna w Warszawie.

Oleśniewicz, P. \& Widawski, K. (2013). Turystyka edukacyjna w kontekście turystyki szkolnej: wybrane zagadnienia. Wrocław, Instytut Geografii i Rozwoju Regionalnego Uniwersytetu Wrocławskiego.

Śniadek, J. (2006). Age of seniors - a challenge for tourism and leisure industry. Studies in Physical Culture and Tourism, 13(suppl.), 103-105.

UNWTO (2016). Tourism Highlights 2016 Edition.

Widawski, K. (2010). Accessibility and the character of the information about tourist values in the Internet on the example of the folklore events. In: Chromý, J. (ed.). Trendy komunikace v cestovním ruchu. Praha, Verbum, pp. 94-113.

Widawski, K. (2011). Accessible tourism starts with the accessible information. Madrid case study. In: Wyrzykowski, J. \& Marak, J. (eds.). Tourism role in the regional economy. Social, health-related, economic and spatial conditions of disabled people's tourism development. Wrocław, University of Business in Wrocław, pp. 298-310.

\section{Corresponding author:}

Julita Markiewcz-Patkowska, PhD., Eng.

julita.markiewicz-patkowska@wsb.wroclaw.pl 